Journal of Islamic Medicine

Volume 2 (4) (2018), Pages 33-43

\title{
PENGARUH PEMBERIAN DIET TINGGI LEMAK TERHADAP KONSENTRASI SECRETORY IMMUNOGLOBULIN A (sIgA) SALIVA TIKUS PUTIH Rattus norvegicus YANG DIINDUKSI BAKTERI Aggregatibacter actinomycetemcomitans (Aa)
}

\author{
Risma Aprinda Kristanti ${ }^{1}$ \\ ${ }^{1}$ Program Studi Pendidikan Dokter Fakultas Kedokteran dan Imu-ilmu Kesehatan \\ Universitas Islam Negeri Maulana Malik Ibrahim Malang \\ E-mail: risma.aprinda@yahoo.com
}

\begin{abstract}
ABSTRAK
Hiperlipidemia menyebabkan perubahan pada sel imun dan proses penyembuhan luka, sehingga juga meningkatkan kemungkinan untuk terserang periodontitis yang terutama disebabkan oleh bakteri Aggregatibacter actinomycetemcomitans (Aa) atau infeksi lainnya. Asam lemak yang berlebihan dapat menghambat proliferasi sel karena hasil peroksidasi lipid yang bersifat toksik bagi sel. Asam lemak juga ikut mempengaruhi produksi dan modulasi sitokin karena asam lemak dapat menyebabkan reduksi proliferasi limfosit. Diet tinggi lemak telah menyebabkan penurunan jumlah limfosit B. Pada perkembangannya, limfosit B membentuk sel B memori dan sel plasma yang memproduksi antibodi, termasuk IgA. Penelitian ini bertujuan untuk mengetahui pengaruh pemberian diet tinggi lemak dan induksi bakteri Aa terhadap konsentrasi secretory Immunoglobulin A (sIgA) saliva. Sebanyak 28 tikus Rattus norvegicus Strain Wistar dibagi dalam empat kelompok secara random, kelompok K0 diberi pakan standar, kelompok K1 diberi pakan standar kemudian diinduksi bakteri Aa, kelompok K2 diberikan diet tinggi lemak, dan kelompok K3 diberikan diet tinggi lemak kemudian diinduksi bakteri Aa. Pada akhir penelitian seluruh tikus diambil cairan saliva dan diukur konsentrasi sIgA saliva menggunakan metode ELISA. Dari hasil penelitian menunjukkan bahwa terdapat perbedaan yang signifikan konsentrasi sIgA saliva antara kelompok pakan standar tanpa induksi bakteri Aa (K0) dengan kelompok diet tinggi lemak tanpa induksi bakteri Aa (K2) dan antara kelompok pakan standar dengan induksi bakteri Aa (K1) dengan kelompok diet tinggi lemak dengan induksi bakteri Aa (K3)
\end{abstract}

\section{PENDAHULUAN}

Berdasarkan data yang didapatkan dari Badan Pusat Statistik (BPS) tentang rata-rata konsumsi kalori per kapita per hari untuk tahun 2009 dengan berbagai indikator kelompok makanan, diketahui bahwa indikator minyak dan lemak didapatkan sebesar 228,35 $\mathrm{Kal} /$ kapita/hari, menempati urutan ketiga setelah indikator makanan jadi $(278,46$ $\mathrm{Kal} / \mathrm{kapita} / \mathrm{hari}$ ). Hal ini menunjukkan bahwa telah terjadi perubahan pola makan sebagai akibat dari perubahan gaya hidup (Calder, 2005). Faktor makanan merupakan salah satu faktor utama penyebab meningkatnya simpanan lemak dalam kelenjar saliva (Nagato and Masuno, 1993). Semakin meningkat konsumsi lemak, akan menyebabkan hiperlipidemia (Marian et al., 1988). 
Konsumsi lemak yang berlebihan dapat meningkatkan profil lemak dalam plasma dan simpanan lemak dalam jaringan (Zulet et al., 1999), termasuk juga dapat menyebabkan akumulasi lemak pada sel parenkimal kelenjar saliva sehingga menyebabkan perubahan morfologi pada sel duktus dan asini (Anderson et al., 1994).

Telah lama diketahui bahwa asam lemak dapat mempengaruhi sistem imun (Meade and Mertin, 1978; Clamp et al., 1997). Selain itu, hiperlipidemia ternyata juga menyebabkan perubahan pada sel imun dan proses penyembuhan luka, sehingga juga meningkatkan kemungkinan untuk terserang periodontitis atau infeksi lainnya (Iacopino and Cutler, 2000).

Asam lemak yang berlebihan dapat menghambat proliferasi sel karena hasil peroksidasi lipid yang bersifat toksik bagi sel (De Pablo and De Cienfuegos, 2000). Asam lemak juga ikut mempengaruhi produksi dan modulasi sitokin karena asam lemak dapat menyebabkan reduksi proliferasi limfosit (Endres et al., 1989; De Pablo et al., 1998; Endres, 1996). Chui et al. (2012) membuktikan bahwa diet tinggi lemak telah menyebabkan penurunan jumlah limfosit B. Pada perkembangannya, limfosit B membentuk sel B memori dan sel plasma yang memproduksi antibodi, termasuk IgA (Roeslan, 2002).

Penelitian Cabrera et al. (2012) menunjukkan bahwa diet tinggi lemak yang diberikan kepada hewan coba dapat menurunkan ekspresi toll like receptor 2 (TLR2) dan TLR6 diikuti dengan penurunan ekspresi Interleukin-6 (IL-6). Interleukin-6 merupakan faktor induksi utama pada diferensiasi fase terminal proses pembentukan antibodi oleh sel limfosit B. Interleukin-6 menginduksi sel limfosit B untuk mempercepat sekresi IgA oleh sel limfosit B dalam Payers Patch (Kresno, 2010). Penelitian oleh Mohammed (2012) juga menunjukkan bahwa diet tinggi lemak yang diberikan pada hewan coba yang telah mengalami kehilangan polymeric immunoglobulin receptor (pIgR) menurunkan ekspresi IL-6.

Berdasarkan penelitian-penelitian sebelumnya, perlu diketahui bahwa periodontitis terutama disebabkan oleh bakteri Aggregatibacter actinomycetemcomitans (Aa) (Sanz et al, 2004). Namun, daya tahan tubuh dan imunitas yang lemah juga dapat memicu terjadinya periodontits (Haake et al., 2002). Hagewald et al. (2000) menemukan bahwa melemahnya sistem imun dapat menjadi faktor risiko periodontitis, terdapat penurunan konsentrasi Imunoglobulin (IgA) dalam saliva yang cukup signifikan pada kelompok Generalised Early-Onset Periodontitis (GEOP). Ada hubungan antara tingkat keparahan inflamasi gingiva dan periodontal dengan konsentrasi IgA (Guven and De Visscher, 1982). Penelitian Flemmig et al (1996) menunjukkan bahwa terdapat peningkatan kadar sIgA saliva sebagai respon terhadap bakteri Aa pada penderita juvenile periodontitis. Penelitian Almeida et al (2011) menunjukkan bahwa penderita penyakit periodontal dengan kadar secretory $\operatorname{Ig} \mathrm{A}(\mathrm{sIg} \mathrm{A})$ yang lebih rendah memiliki risiko untuk menderita penyakit periodontal yang lebih parah.

Aggregatibacter actinomycetemcomitans ( $\mathrm{Aa}$ ) termasuk ke dalam golongan bakteri gram negatif anaerob fakultatif, merupakan bakteri patogen penyebab localized juvenile periodontitis (Zambon et al., 1983). Selain itu, bakteri Aa juga memiliki pengaruh besar menyebabkan periodontitis jenis lainnya (Tolo and Helgeland, 1991). Peningkatan jumlah Aa dalam subgingiva dapat menyebabkan meningkatnya keparahan periodontitis (Haffajee and Socransky, 1994).

Walaupun bakteri Aa ada dalam jumlah kecil dalam subgingiva, tetapi dapat memicu respon imun yang cukup signifikan pada saat seseorang terinfeksi bakteri ini (Moore and Moore, 1994; Ebersole et al., 1991). Sebagai perlindungan terhadap host, akan dibentuk antibodi untuk melawan bakteri ini. Peningkatan sIgA saliva telah terbukti dapat meminimalisir terjadinya perdarahan gingiva (Schenck et al., 1993). 


\section{METODE PENELITIAN}

Penelitian ini tergolong penelitian eksperimental laboratoris, dengan menggunakan rancangan penelitian post test only control group design. Subyek penelitian dibagi dalam empat kelompok secara random, kelompok K0 diberi pakan standar, kelompok K1 diberi pakan standar kemudian diinduksi bakteri Aa, kelompok K2 diberikan diet tinggi lemak, dan kelompok K3 diberikan diet tinggi lemak kemudian diinduksi bakteri Aa

\section{Sampel}

Sampel yang digunakan dalam penelitian ini adalah tikus putih Rattus norvegicus Strain Wistar jenis kelamin jantan, usia 40-60 hari sebanyak 28 ekor, berat 150-200 gram yang ada di Laboratorium Hewan Coba Fakultas Saintek Universitas Islam Negeri Maulana Malik Ibrahim (UIN Maliki) Malang.

Subyek penelitian dibagi dalam empat kelompok secara random, kelompok I (K1) adalah kelompok yang diberi pakan standar selama 35 hari, kelompok II (K2) adalah kelompok yang diberi pakan standar selama 35 hari, pada hari ke-29 diinduksi bakteri Aa selama 7 hari, kelompok III (K3) adalah kelompok yang diberi diet tinggi lemak selama 35 hari, dan kelompok IV (K4) adalah kelompok yang diberi diet tinggi lemak selama 35 hari, pada hari ke-29 diinduksi bakteri Aa selama 7 hari

\section{Pembuatan dan Pemberian Diet Tinggi Lemak}

Pakan tinggi lemak terbuat dari emulsi lemak sapi yang terdiri dari 5 gram lemak sapi, 10 gram kuning telur, dan air sampai $100 \mathrm{ml}$. Cara pembuatannya yaitu dengan memanaskan lemak sapi yang berupa padatan sehingga diperoleh bentuk cair (minyak lemak sapi). Kemudian mencampur minyak sapi tersebut dengan kuning telur sehingga terbentuk korpus emulsi, kemudian ke dalam korpus emulsi tersebut ditambahkan air sampai $100 \mathrm{ml}$ sambil diaduk cepat sehingga terbentuk emulsi yang halus dan homogen. Emulsi lemak sapi ini dibuat baru setiap hari sebelum diberikan secara per oral menggunakan sonde oral sebanyak $3 \mathrm{ml} /$ tikus selama perlakuan diet tinggi lemak (Widyaningsih, 2011).

\section{Induksi Periodontitis Pada Hewan Coba}

Bakteri Aa diinduksikan pada daerah interdental gingiva insisiv bawah tikus sebanyak 200 mikroliter yang mengandung $10^{8}$ bakteri Aa sambil bibir bawah tikus digerak-gerakan.

\section{Pengambilan Data}

Pengumpulan saliva dilakukan di daerah sublingualis cavum oris hewan coba dengan mikropipet berskala dan dicatat volumenya. Sebelum pengambilan saliva, dibuat sediaan injeksi pilokarpin dengan cara menambahkan $15 \mathrm{ml}$ aquadest distilatta ke dalam $5 \mathrm{ml}$ larutan pilokarpin $\mathrm{HCl}$.

Sediaan injeksi pilokarpin diinjeksikan secara subkutan pada tikus sebanyak $1,5 \mathrm{ml}(0,75$ $\mathrm{mg} / 100$ gram) per tikus. Setelah itu ditunggu $\pm 10-15$ menit dan mulai dilakukan pengambilan saliva sebanyak 50 mikroliter per tikus menggunakan mikropipet.

Selanjutnya sampel saliva dikirim ke Laboratorium Genetika Fakultas Saintek UIN Maliki Malang untuk dilakukan pemeriksaan konsentrasi sIgA menggunakan metode ELISA. 


\section{HASIL PENELITIAN}

Berdasarkan penelitian yang telah dilakukan didapatkan data berat badan awal dan akhir tikus sebagai berikut :

Tabel 1. Nilai rerata (mean) dan simpang baku (SD) BB awal tikus pada kelompok K0, K1, K2, dan K3

\begin{tabular}{|c|c|c|}
\hline Kelompok & n & Mean dan SD \\
\hline K0 & 6 & $118,67 \pm 6,53$ \\
K1 & 6 & $124,83 \pm 17,09$ \\
K2 & 6 & $113,67 \pm 13,89$ \\
K3 & 6 & $109,33 \pm 15,81$ \\
\hline Total & 24 & $116,62 \pm 14,28$ \\
\hline
\end{tabular}

Tabel 2. Nilai rerata (mean) dan simpang baku (SD) BB akhir tikus pada kelompok K0, K1, K2, dan K3

\begin{tabular}{|c|c|c|c|c|c|}
\hline \multicolumn{3}{|c|}{ Pakan Standar } & \multicolumn{3}{c|}{ Diet Tinggi Lemak } \\
\hline Kelompok & $\mathrm{n}$ & Mean dan SD & Kelompok & $\mathrm{n}$ & Mean dan SD \\
\hline K0 & 6 & $189,67 \pm 25,22$ & K2 & 6 & $186,33 \pm 16,13$ \\
K1 & 6 & $170,17 \pm 26,36$ & K3 & 6 & $195,50 \pm 27,37$ \\
\hline Total & 12 & $179,92 \pm 26,62$ & Total & 12 & $190,92 \pm 21,95$ \\
\hline
\end{tabular}

Sedangkan hasil statistik deskriptif untuk konsentrasi sIgA saliva dapat dilihat pada Tabel 3 berikut:

Tabel 3. Nilai rerata (mean) dan simpang baku (SD) konsentrasi sIgA saliva tikus pada kelompok K0, K1, K2, dan K3

\begin{tabular}{|c|c|c|c|c|c|}
\hline \multicolumn{3}{|c|}{ Pakan Standar } & \multicolumn{3}{|c|}{ Diet Tinggi Lemak } \\
\hline Kelompok & $\mathrm{n}$ & Mean dan SD & Kelompok & $\mathrm{n}$ & Mean dan SD \\
\hline K0 & 6 & $6199,7 \pm 745,94$ & $\mathrm{~K} 2$ & 6 & $4379,2 \pm 306,08$ \\
\hline K1 & 6 & $7328,5 \pm 1029,01$ & K3 & 6 & $5410,2 \pm 475,51$ \\
\hline Total & 12 & $6764,08 \pm 1040,07$ & Total & 12 & $4894,67 \pm 659,74$ \\
\hline
\end{tabular}

Data terlebih dahulu diuji normalitas menggunakan uji normalitas Saphiro-Wilk dan didapatkan hasil untuk BB awal, BB akhir, dan konsentrasi sIgA saliva pada kelompok K0, K1, $\mathrm{K} 2$, dan $\mathrm{K} 3$ bahwa $\mathrm{p}>0,05$ yang berarti bahwa data berdistribusi normal. 
Untuk mengetahui homogenitas variasi dilakukan uji Levene Test pada variabel konsentrasi sIgA saliva. Data pada variabel diperoleh $\mathrm{p}<0,05$ sehingga variasi antar kelompok tidak homogen.

Hasil data yang diperoleh berdistribusi normal dan tidak homogen $(\mathrm{p}<0,05)$, maka untuk mengetahui beda variabel konsentrasi sIgA saliva antar kelompok menggunakan Brown-Forsythe Test. Hasil dari Brown-Forsythe Test menunjukkan bahwa nilai p untuk variabel konsentrasi sIgA saliva adalah 0,000 yang berarti konsentrasi sIgA saliva berbeda secara bermakna antar kelompok $(\mathrm{p}<0,05)$.

Untuk mengetahui antar kelompok mana yang berbeda pada variabel konsentrasi sIgA saliva yang memiliki data berdiribusi normal dan variasi antar kelompok tidak homogen, dilanjutkan dengan uji Games-Howell. Hasil uji dapat dilihat pada Tabel 4 dan Grafik 1 berikut ini :

Tabel 4. Hasil uji beda Games-Howell variabel konsentrasi sIgA saliva pada kelompok K0, $\mathrm{K} 1, \mathrm{~K} 2$ dan K3

\begin{tabular}{|c|c|c|}
\hline Kelompok & $\mathbf{P}$ & Keterangan \\
\hline K0 dan K1 & 0,201 & Tidak Signifikan \\
\hline K0 dan K2 & 0,004 & Signifikan \\
\hline K0 dan K3 & 0,203 & Tidak Signifikan \\
\hline K1 dan K2 & 0,002 & Signifikan \\
\hline K1 dan K3 & 0,017 & Signifikan \\
\hline K2 dan K3 & 0,008 & Signifikan \\
\hline
\end{tabular}

p: signifikan pada $\mathrm{p}<0,05$ 


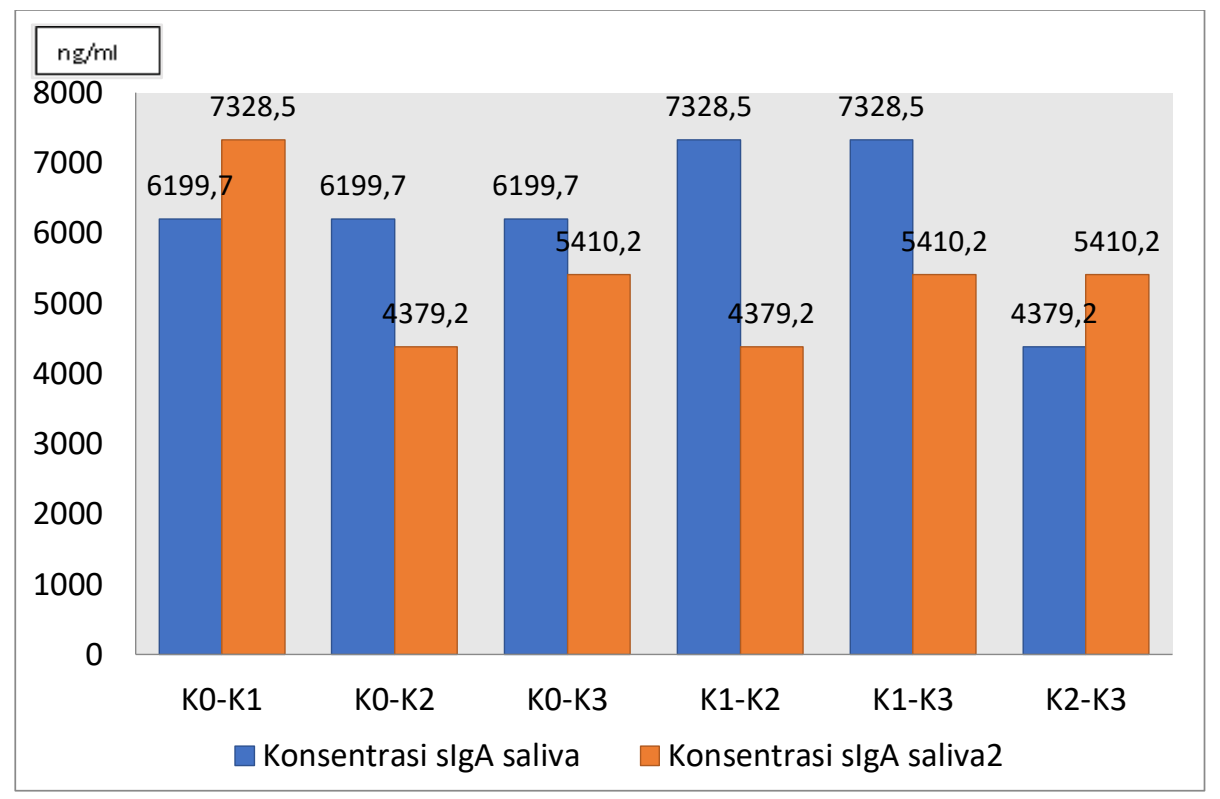

Grafik 1. Grafik rerata konsentrasi sIgA saliva pada kelompok K0, K1, K2, dan K3

Keterangan:

K0 : kelompok pakan standar tanpa induksi bakteri Aa

K1 : kelompok pakan standar dengan induksi bakteri Aa

K2 : kelompok diet tinggi lemak tanpa induksi bakteri Aa

K3 : kelompok diet tinggi lemak dengan induksi bakteri Aa

Berdasarkan Tabel 4, menunjukkan terdapat perbedan signifikan konsentrasi sIgA saliva $(\mathrm{p}<0,05)$ antara kelompok K0 dan kelompok K2, antara kelompok K1 dan kelompok K2, antara kelompok K1 dan kelompok K3, serta antara kelompok K2 dan kelompok K3.

Perbedaan konsentrasi sIgA saliva tidak bermakna $(\mathrm{p}>0,05)$ antara kelompok K0 dan $\mathrm{K} 1(\mathrm{p}=0,201)$ serta antara kelompok K0 dan K3 $(\mathrm{p}=0,203)$.

\section{DISKUSI}

\section{Hubungan Diet Tinggi Lemak dan Konsentrasi sIgA saliva}

Rerata konsentrasi sIgA pada kelompok yang diberi pakan standar adalah 6199,7 ng/ml dan $7328,5 \mathrm{ng} / \mathrm{ml}$. Sedangkan rerata konsentrasi sIgA saliva pada kelompok yang diberi diet tinggi lemak adalah $4379,2 \mathrm{ng} / \mathrm{ml}$ dan $5410,2 \mathrm{ng} / \mathrm{ml}$. Terdapat perbedaan yang signifikan konsentrasi sIgA saliva antara kelompok pakan standar tanpa induksi bakteri Aa (K0) dengan kelompok diet tinggi lemak tanpa induksi bakteri Aa (K2) dan antara kelompok pakan standar dengan induksi bakteri Aa (K1) dengan kelompok diet tinggi lemak dengan induksi bakteri Aa (K3). Hal ini menunjukkan bahwa konsentrasi sIgA saliva pada kelompok yang diberi diet tinggi lemak lebih rendah dibandingkan konsentrasi sIgA pada kelompok yang diberi pakan standar.

Perbedaan konsentrasi sIgA saliva tidak bermakna antara kelompok K0 dengan K1 dan antara kelompok K0 dengan K3. Perbedaan yang tidak bermakna antara kelompok K0 dan K3 tersebut dapat disebabkan karena pada kelompok yang diinduksi bakteri Aa terjadi peningkatan konsentrasi sIgA sebagai respon terhadap inflamasi yang terjadi. 
Hiperlipidemia menyebabkan akumulasi lemak intraseluler pada kelenjar saliva sehingga menyebabkan terganggunya fungsi ekskresi kelenjar saliva (Moubarak, 2008; Pisiriciler et al., 2009). Konsentrasi $\operatorname{sg} \mathrm{A}$ saliva sangat dipengaruhi laju rata-rata aliran saliva (Marcotte and Lavoie, 1998), sehingga menurunnya laju rata-rata aliran saliva akan menyebabkan konsentrasi sIgA saliva ikut menurun.

Penelitian Cabrera et al. (2012) menunjukkan bahwa diet tinggi lemak yang diberikan kepada hewan coba dapat menurunkan ekspresi toll like receptor 2 (TLR2) dan TLR6 diikuti dengan penurunan ekspresi Interleukin-6 (IL-6). Interleukin-6 merupakan faktor induksi utama pada diferensiasi fase terminal proses pembentukan antibodi oleh sel limfosit B. Interleukin-6 menginduksi sel limfosit B untuk mempercepat sekresi IgA oleh sel limfosit B dalam Payers Patch (Kresno, 2010). Penelitian oleh Mohammed (2012) juga menunjukkan bahwa diet tinggi lemak yang diberikan pada hewan coba yang telah mengalami kehilangan polymeric immunoglobulin receptor ( $\mathrm{pIgR}$ ) menurunkan ekspresi IL-6. polymeric immunoglobulin receptor merupakan reseptor spesifik untuk polimer immunoglobulin, termasuk Immunoglobulin A (Roeslan, 2002).

\section{Hubungan Induksi Bakteri Aa dan Konsentrasi sIgA Saliva}

Hasil analisis deskriptif menunjukkan bahwa rerata konsentrasi sIgA saliva pada tikus yang diberi pakan standar tanpa induksi periodontitis adalah $6199,7 \mathrm{ng} / \mathrm{ml}$, dan rerata konsentrasi sIgA pada tikus yang diberi pakan standar dengan induksi periodontitis adalah 7328,5 ng/ml. Sedangkan untuk rerata konsentrasi sIgA saliva pada tikus yang diberi diet tinggi lemak tanpa induksi periodontitis adalah $4379,2 \mathrm{ng} / \mathrm{ml}$, dan rerata konsentrasi $\mathrm{sIgA}$ pada tikus yang diberi diet tinggi lemak dengan induksi periodontitis adalah 5410,2 ng/ml. Hal ini menunjukkan bahwa pada kelompok yang diberi induksi periodontitis memiliki rerata konsentrasi sIgA yang lebih tinggi.

Peningkatan konsentrasi sIgA saliva pada kelompok yang diinduksi periodontitis disebabkan karena meningkatnya konsentrasi IgA serum akibat peningkatan permeabilitas epitel krevikular gingiva karena inflamasi gingiva akibat induksi bakteri (Marcotte and Lavoie, 1998).

Antigen bakteri, yang dapat berupa endotoksin berpenetrasi ke dalam jaringan gingiva dan menimbulkan respon penjamu sistemik dan lokal. Limfosit di dalam darah tepi umumnya meningkat reaktivitasnya terhadap antigen pada kelainan periodontal (Roeslan, 2002). Adanya peningkatan jumlah antigen pada lapisan bofilm dapat memicu respon sIgA saliva (Marcotte and Lavoie, 1998).

\section{Pengaruh Pemberian Diet Tinggi Lemak Terhadap Konsentrasi sIgA Saliva Tikus Rattus norvegicus Yang Diinduksi Bakteri Aa}

Hasil analisis deskriptif menunjukkan bahwa rerata konsentrasi sIgA saliva pada tikus yang diberi pakan standar tanpa induksi bakteri Aa adalah 6199,7 ng/ml, dan rerata konsentrasi sIgA pada tikus yang diberi pakan standar dengan induksi bakteri Aa adalah 7328,5 ng/ml. Sedangkan untuk rerata konsentrasi sIgA saliva pada tikus yang diberi diet tinggi lemak tanpa induksi bakteri Aa adalah 4379,2 ng/ml, dan rerata konsentrasi sIgA pada tikus yang diberi diet tinggi lemak dengan induksi bakteri Aa adalah 5410,2 ng/ml. Hal ini menunjukkan bahwa pada kelompok yang diberi induksi bakteri Aa memiliki rerata konsentrasi sIgA yang lebih tinggi.

Peningkatan konsentrasi sIgA saliva pada kelompok yang diinduksi bakteri Aa disebabkan karena meningkatnya konsentrasi IgA serum akibat peningkatan permeabilitas epitel krevikular gingiva karena inflamasi gingiva akibat induksi bakteri (Marcotte and Lavoie, 1998). 
Antigen bakteri, yang dapat berupa endotoksin berpenetrasi ke dalam jaringan gingiva dan menimbulkan respon penjamu sistemik dan lokal. Limfosit di dalam darah tepi umumnya meningkat reaktivitasnya terhadap antigen pada kelainan periodontal (Roeslan, 2002). Adanya peningkatan jumlah antigen pada lapisan bofilm dapat memicu respon SIgA saliva (Marcotte and Lavoie, 1998).

Kuning telur mengandung polyunsaturated fatty acid (PUFA) yang memilki kemampuan sebagai prekursor antioksidan dan antiinflamasi (Simopoulos and Salem, 1992; Werner and Seymour, 2009). Penelitian Chapple et al., (2007) menunjukkan bahwa pasien dengan diet PUFA memiliki tingkat keparahan penyakit periodontal yang lebih rendah dibandingkan dengan pasien yang kurang mengkonsumsi PUFA dalam makanannya.

Imunoglobulin G, IgM, dan IgA terhadap berbagai mikroorganisme rongga mulut ditemukan di dalam serum. Namun, tidak terdeteksi adanya peningkatan pada penderita kelainan periodontal. Secara in vitro, sIgA saliva dapat menghambat perlekatan, agregasi, dan kolonisasi Streptococcus salivarius dan Streptococcus mutans pada proses pembentukan plak gigi dan karies gigi. Dengan demikian, sIgA saliva berperan dalam mekanisme pertahanan tubuh terhadap terjadinya karies gigi, dan bukan penyakit jaringan periodontal (Roeslan, 2002).

\section{KESIMPULAN}

Pada penelitian ini, pemberian diet tinggi lemak dapat mempengaruhi konsentrasi sIgA saliva pada tikus jantan Rattus norvegigus Strain Wistar yang diinduksi bakteri Aa

\section{DAFTAR PUSTAKA}

Almeida LSB, Alves CMC, Lopes FF, Pereira AFV, Guerra RNM, and Pereira ALA. 2011. Salivary IgA and Periodontal Treatment Needs in Diabetic Patient. Braz Oral Res. Vol 25(6)

Anderson LC, Suleiman AH, Garrett JR. 1994. Morphological Effects of Diabetes on The Granular Ducts and Acini of The Rat Submandibular Gland. Microsc Res Techn. Vol 27

Cabrera GB, Luna E, Miller HB, and Diaz JCC. 2012. Mice Fed With A High Fat Diet Show A Decrease in The Expression of Toll Like Receptor (TLR) 2 and TLR6 mRNAs in Adipose and Hepatic Tissues. Nutricion Hospitalaria. Vol 27(4)

Calder, PC. 2005. Polyunsaturated Fatty Acids And Inflammation. Biochem Soc Trans. Vol 33. pp. $423-427$

Chapple IL, Milward M, Dietrich T. 2007. The Prevalence Of Inflammatory Periodontitis Is Negatively Associated With Serum Antioxidant Concentration. J Nutr. Vol 137

Chui J, Xiao Y, Shi YH, Wang B. 2012. Lipoic Acid Attenuates High Fat Diet Induced Oxidative Stress and B-Cell Related Immune Depresion. Nutrition. Vol 28 
Clamp AG, Ladha S, Clark DC, Grimble RF, Lund EK. 1997. The Influence of Dietary Lipids on The Composition and Membrane Fluidity of Rat Hepatocyte Plasma Membrane. Lipids. Vol 32

De Pablo MA and De Cienfuegos GA. 2000. Modulatory Effects of Dietary Lipids on Immune System Functions. Immunol Cell Biol. Vol 78

De Pablo MA, Ortega E, Gallego AM, Alvarez C, Pancorbo PL, Alvarez de Cienfuegos G. 1998. The Effect of Dietary Fatty Acid Manipulation on Phagocytic Activity and Cytokine Production by Peritoneal Cells from Balb/c Mice. J Nutr Sci Vitaminol. Vol 44

Ebersole JL, Cappelli D, Mott GE, Kesavalu L, Holt SC, Singer RE. 1999. Systemic Manifestations of Periodontitis in The Non Human Primate. J Periodont Resp. Vol. 34

Endres S. 1996. N-3 Polyunsaturated Fatty Acids and Human Cytokine Synthesis. Lipids. Vol 31

Endres S et al. 1989. The Effect of Dietary Supplementation with n-3 Polyunsaturated Fatty Acids on the Synthesis of Interleukin-1 and Tumor Necrosis Factor By Mononuclear Cells. N Engl J Med. Vol 320

Flemmig TF, Selmair I, Schmidt H, and Karch H. 1996. Specific Antibody Reactivity Against A 110 Kilodalton Actinobacillus actinomycetemcommitans Protein in Subject with Periodontitis. Clinical and Diagnostic Laboratory Immunology. Vol 3(6)

Güven O, De Visscher JG. 1982. Salivary IgA in Periodontal Disease. J Periodontol. Vol.53(5)

Haake SK, Nisengard RJ, Newmann MG, Miyasaki KT. 2002. Microbial Interactions With the Host in Periodontal Diseases. Dalam Clinical Periodontology, $9^{\text {th }}$ ed. W.B Saunders Co. Philadelphia, London, Toronto. 134 - 45

Haffajee AD and Socransky SS. 1994. Microbial Etiological Agents of Destructive Periodontal Disease. Periodontology 2000. Vol 5

Hagewald S, Bernimoulin JP, Kottgen E, and Kage A. 2000. Total IgA and Porphyromonas gingivalis-Ractive IgA in The Saliva of Patients with Generalised Early-Onset Periodontitis. Eur J Oral Sci. Vol 108(2)

Iacopino AM and Cutler CW. 2000. Pathophysiological Relationship Between Periodontitis and Systemic Disease: Recent Concepts Involving Serum Lipids. J Periodontol. Vol 71

Marian, Maltese, Eschlean. 1988. Cardiovascular Disease; Hypertension, Congestive Heart Failure in Introductory Nutrition Diet Therapy. St Louis Mosby Company

Marcotte H and Lavoie MC. 1998. Oral Microbial Ecology and The Role of Salivary Immunoglobulin A. Micobiology and Molecular Biology Reviews. Vol 62 (1)

Meade CJ and Mertin J. 1978. Fatty Acids and Immunity. Adv Lipid Res. 16. 
Mohammed, NK. 2012. Diet, Bacteria and Inflammation: The Intestinal Mucosa and Metabolic Syndrome. Dissertation. University of Kentucky UKnowledge

Moore WEC \& Moore LVH. 1994. The Bacteria of Periodontal Diseases. Periodontol 2000. 5: 66-77

Nagato T and Masuno H. 1993. Lipid Droplet Acumulation and Lipoprotein Lipase Activity in The Rat Salivary Gland During The Perinatal Period. Arch Oral Biol. Vol 38

Pisiriciler R, Alturfan EE, Caliskan E, Yarat A. 2009. Impact of Experimental Hyperlipidemia On Histology of Major Salivary Glands. Medical Journal of Trakya University. Vol.26(4). pp:283-291

Roeslan, BO. 2002. Imunologi Oral. Kelainan di Dalam Rongga Mulut. Jakarta: BP-FKUI

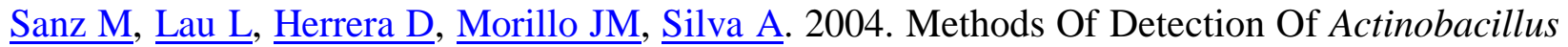
actinomycetemcomitans, Porphyromonas gingivalis and Tannerella forsythensis In Periodontal Microbiology, With Special Emphasis On Advanced Molecular Techniques: A Review. J Clin Periodontol. Vol 12

Schenck K, Poppelsdorf D, Denis C, and Tollefsen T. 1993. Levels of Salivary IgA Antibodies Reactive With Bacteria From Dental Plaque Associated With Susceptibility to Experimental Gingivitis. J Clin Periodontol. Vol 20

Simopoulus AP and Salem Jr N. 1992. Egg Yolk As A Source Of Long-Chain Polyunsaturated Fatty Acids In Infant Feeding. Am J Clin Nutr. Vol 55

Tolo K and Helgeland K. 1991. Fc-binding Components: A Virulence Factor in Actinobacillus actinomycetemcomitans?. Oral Microbiol Immunol. Vol 6

Widyaningsih, W. 2011. Efek Ekstrak Etanol Rimpang Temugiring (Curcuma heyneana val) Terhadap Kadar Trigiserida. Jurnal Ilmiah Kefarmasian. Vol 1(1)

Werner CW and Seymour RA. Are Alcohol Containing Mouthwashes Safe?. 2009. Br Dental J. Vol 207

Zambon JJ, Christersson LA, and Slots J. 1983. Actinobacillus actinomycetemcomitans in Human Periodontal Disease. Prevalence in Patient Groups and Distribution of Biotypes and Serotypes Within Families. J Periodontol. Vol 54

Zulet MA, Barber A, Garcin H, Higueret P, and Martinez JA. Alteration in Carbohydrates and Lipid Metabolism Induced by a Diet Rich in Coconut Oil and Cholesterol in a Rat Model. Journal of The American Collage of Nutrition 18(1). 1999 